\title{
Gender Differences in Child Care and Work: An Interdisciplinary Perspective
}

\author{
ELIZABETH M. HILL* \\ The University of Michigan
}

M. ANNE HILL

Queens College of the City University of New York

\begin{abstract}
During the past several decades, women have increased their labor-force participation while remaining primarily responsible for the care of children. Men have not correspondingly increased their home activity, and women's earnings have not reached parity with men's. A primary reason that women have failed to gain equality in the labor market may be the remaining inequalities in provision of child rearing. We consider the constraints on child rearing faced by men and review literature on animal behavior to elucidate the conditions that facilitate parental investment by males. Some factors appear to have congruent effects, in general, on paternal behavior in many species: the benefit to young of male help, the male capacity for providing help, and paternity certainty. We discuss the role of these factors in slowing the achievement of gender equality and the potential efficacy of social policy in changing existing behavior patterns.
\end{abstract}

\section{INTRODUCTION}

Many women today belong to a generation caught in transition. In the past decades, rising rates of female labor-force participation have been concurrent with increases in the divorce rate, the percent of households headed by women, and the rate of births to unmarried women. ${ }^{(4)}$ Even though women

*Direct all correspondence to: Elizabeth M. Hill, Ph.D., Department of Psychiatry, The University of Michigan Alcohol Research Center, 400) E. Eisenhower Parkway, Ann Arbor, MI 48104.

The Journal of Behavioral Economics, Volume 19, Number 1, pages 81-101

Copyright 1990 by JAI Press Inc.

All rights of reproduction in any form reserved.

ISSN: 0035-7634 
have taken on new economic responsibility, they remain primarily responsible for child care. Single women who head families bear not only domestic and child care responsibility, but primary financial responsibility as well. Married mothers, even if working full-time, bear disproportionate responsibility for home and children, as will be discussed in detail.

Currently, about one in five families with children are headed by women. In 1982, about half of these female-headed families were living in poverty, compared to 10 percent of other types of families. ${ }^{\left({ }^{(13)}\right)}$ The earning differential between men and women may be the most important determinant of the low income of separated and divorced women who head families. ${ }^{\left({ }^{22)}\right)}$ In 1987 the average weekly earnings of full time, year-round women workers was 70.7 percent of men's earnings in the United States. ${ }^{(114)}$ Much of the wage gap can be explained by differences between men and women in their occupational distribution, levels of schooling and job-related skills, yet even if we account for these differences, the wage gap remains substantial.(11.12) The amount of the wage gap left unexplained by variation in measured characteristics is often attributed to discrimination against women in the labor market. Becker, ${ }^{(5)}$ in contrast, specifies a model wherein women who expend considerable energies in their varied domestic demands supply less "effort" (or energy) to the job than do men, and as a result receive lower wages.

Therefore, many of today's mothers face a "double-bind." Women who both work full-time and are primarily responsible for child care may sacrifice some career advancement and earnings as they enter occupations compatible with child rearing (e.g., those with less travel, more flexible hours, and/or less occupational risk). Women who choose to drop out of the labor force completely during the period in which they bear and rear children will sacrifice on-the-job training, may lose some of their previous investment in "human capital" through depreciation (especially if they are highly trained in rapidly-changing fields), and clearly sacrifice earnings over the lifetime. ${ }^{(87)}$ There still remains a large degree of occupational segregation, with the majority of working women employed in predominantly female occupations. ${ }^{(111}$ Consequently, changing the earnings differential may require either greater pay equality across occupations or a dramatic change in the distribution of women across occupations.

This paper addresses several issues, with its central tenet that women are not treated equally in the labor market largely because they provide a disproportionate share of time and energies in child rearing. We will discuss the foundations for this pattern: the relationship of the sexual division of labor to the vastly prolonged time required for infant development and the effects of child care on economic activity. We draw on the extensive 
literature of animal behavior to examine conditions that facilitate parental investment by males in other species. ${ }^{(1165)}$ A comparative analysis, while of controversial relevance, may provide clues concerning the changes necessary to reverse such trends as the "feminization of poverty". ${ }^{(4)+}$ We assert that potential social policy could be more effective if informed by biological contributions to our resistance to change in social roles.

\section{THE RELATIONSHIP OF CHILD CARE REQUIREMENTS TO PARTICIPATION IN THE LABOR MARKET}

Most animals with single young and large adult-body size have infants whose brains are already well-developed at birth and who require a shorter period of infant dependency. Great apes and humans are exceptions, however. At birth, the brains of human infants are approximately 23 percent of adult size, compared to 68 percent for the rhesus monkey and 45 percent for the chimpanzees. The human brain requires 4 years to attain 95 percent of its growth in volume. ${ }^{178}$ Caring for dependent offspring appears to affect women's labor-force participation. Cross-cultural studies of traditional societies have found that the degree to which women participate in economic activity depends upon the compatibility of work with child care responsibilities. ${ }^{(27)}$ Brown ${ }^{(17)}$ cites examples of such societies revealing that, in most activities like herding large animals, hunting large game, deep-sea fishing, and plow agriculture, the human population is divided into two groups: child-watching members who do not participate and non-child-watching members who do. Among the Ache foragers, women with weaned children produce more food than women with nursing infants. ${ }^{\left({ }^{(3)}\right)}$ Nerlove $^{(91)}$ demonstrated that women's participation in subsistence activities other than gathering was related to supplemental feeding of infants; that is, in societies where women institute supplemental feeding early, women contribute more to subsistence activities.

Similarly, in contemporary industrial societies, higher fertility or higher time-investment in children implies sacrifices in the job market. The wage differential between men and women increases proportionately with the number of children. ${ }^{(+1)}$ In an analysis of an English cohort born in 1946, Joshi and Newell ${ }^{(t))}$ isolated an hourly wage differential of 12 to 14 percent between employed mothers and childless women. This difference was attributable to maternal responsibilities and was primarily caused by loss of employment experience and a higher incidence of part-time employment. Although we cannot be certain of the direction of causality, delayed childbearing (first birth at age 27 or up) is associated with higher female wage. ${ }^{(13)}$ 
Fernandez ${ }^{(37)}$ analyzed data for 5000 employees at five large, technicallyoriented companies. The presence of children, particularly young children, had a strong effect on work behavior. Parents reported missing days at work, leaving work early, dealing with family issues during working hours, and spending unproductive time at work because of child care issues. A much higher percentage of women, regardless of marital status, than married men, experienced problems in scheduling tasks such as child care for sick children, dentist and doctor appointments, and school conferences. About half the women with children under five (versus one-fifth of men) said that child care needs would affect their decision to accept a promotion at least to some extent.

Research with men who are single parents shows the critical effect of child care responsibilities on work performance. The single fathers in the corporate study by Fernandez ${ }^{(37)}$ reported problems with lowered productivity and increased stress as a result of child care, which were similar to those of both married and single women. In a 1981 study of men who became single parents, income decreased for half the men, as a result of several causes: changing to lower-paying jobs that were less demanding, loss of overtime pay, absenteeism to care for ill children, and a loss of social ties with business or professional associates that had contributed income in the past. ${ }^{(55)}$ Over a third of single-parent fathers in another study left their jobs in order to meet parental responsibilities for young children. ${ }^{(42)}$

Parenthood usually has little effect on married men's labor-force participation or pay. ${ }^{(h)}$ In two-parent households, when a child becomes ill, the mother usually stays home whether she is employed full or part-time..$^{(4+)}$ Among married couples, studies using time budgets show that the average husband's contribution to housework or child care is not very responsive to the wife's employment status. ${ }^{.14 .23 .52 .11(1)}$ The impact of family responsibilities on work careers of women was demonstrated in an unusual study comparing parents of disabled children with otherwise similar families. Mothers of disabled children worked significantly fewer hours per week and had significantly lower earnings per hour than other mothers. There was little difference, however, in working hours or earnings among fathers of disabled children. ${ }^{(1 /(k)}$ 'The salient aspect may be that, while most fathers interact with their children, few are responsible for them, being expected to arrange for babysitters or assess when new clothes are needed. ${ }^{175}$

In order for women to participate equally in market activities and thus to be rewarded equally, we face two possibilities. Either economic activities must be carried out concurrently with child care or the extent to which mothers bear primary responsibility for child care must be reduced. We now review behavior among other species in order to isolate factors that can promote investment in offspring by fathers. 


\section{DETERMINANTS OF GENDER DIFFERENCES IN PARENTAL BEHAVIOR IN OTHER ANIMALS}

Many animals exhibit gender differences in mating behavior. Bateman ${ }^{(3)}$ introduced several generalizations based on his classic studies of fruit flies. The variance in reproductive success among individuals of a population is usually higher for males; their success is affected by competition with other males for access to females. In contrast, most females produce about the same number of offspring; reproductive success is limited by their egg production capacity, which is affected by factors such as health. Association between gender and difference in behavior does not prove that gender is the cause of the difference, however. In many species there is variation in female reproductive success through choice of mates, competition with other females for male support, and discerning the best conditions for reproduction. ${ }^{(56)}$ Particularly instructive is a look at species in which sex roles are reversed, such as the Mormon cricket, ${ }^{(+*)}$ the giant water bug, ${ }^{(1)(1 \times)}$ pipefish seahorse, or the Panamanian poison-arrow frog. ${ }^{(121)}$ In these species, females compete aggressively for access to males, whom they court vigorously. ${ }^{(17)}$ Among birds, females of the American Jacana have been observed to be polyandrous; the males brood and care for the clutch of eggs. ${ }^{\left({ }^{49}\right)}$ Moorhen males perform the major tasks involved in egg incubation. Females initiate courtship more often and fight with other females, competing for good-condition males with large fat reserves. ${ }^{(94)}$ The conditions that determine parental behavior do not always preclude male parenting. As will be reviewed, gender roles appear to follow the typical pattern when there are large biological differences in the capacity of males or females to manifest parental behavior and differences in the reliability of genetic relatedness to the offspring.

\section{Male Capacity to Invest}

Bateman ${ }^{(3)}$ interpreted the usual gender difference in animal courtship to be a result of the greater initial investment in eggs by females compared to males' small investment in sperm. In general, the sex that invests more becomes a limited resource for the other sex, generating competition. Parental investment was defined by Trivers ${ }^{(116)}$ as any investment in an individual offspring that increases its chances of survival at the cost of the parents' ability to invest in other offspring. Whether one invests depends both on whether such investment helps the offspring and on the incremental investment required to start ancw. ${ }^{(2 \times)}$ Offspring that have already received investment will probably require less from the parent in the future than would be required if the parent deserted these offspring and started over with new offspring at a later date. The unequal physiological investment in 
the production of egg and sperm may create an initial sex bias in investment, but behavioral sex differences are more striking when female investment is further increased by adaptations such as internal fertilization and gestation. Among amphibians and fish that exhibit parental care, internal fertilization is associated with a decreased likelihood that males will be paternal. ${ }^{(112)}$ In species with external fertilization, the female can depart after spawning, perhaps before the male fertilizes the eggs. In addition, internal fertilization enables further adaptations for internal development of embryos prior to egg laying.

Sex differences in biological investment are important in the occurrence of paternal care; these capacities differ among species. Female mammals are adapted for parental investment with the placenta, internal gestation, and lactation. In birds, either sex can brood, or collect food. In fish, either the male or female can defend the nest, aerate it, and remove parasites. Among 8600 species of birds, 92 percent are monogamous. ${ }^{(13)}$ Among mammals, polygyny is most common; 8 percent of genera are monogamous, another 9 to 10 percent show paternal care such as the provisioning of food, babysitting, and playing. ${ }^{(71)}$ Paternal care is common in social carnivores that have evolved the ability to digest and regurgitate food for young, which either sex can do. Monogamy occurs in only 12 percent of anthropoid primates. ${ }^{(t 7)}$ The need for care from both parents is important in the development of paternal care. Monogamy and male help in care of offspring occur in mammals when a solitary female cannot rear a litter without aid and the carrying capacity of the habitat is insufficient to allow more than one female to breed simultaneously within the same home range. ${ }^{(64)}$

Several theoretical analyses and computer simulations have modeled the paternal decision to remain to help or to desert. ${ }^{(1+.71 .8+1)}$ In order for desertion to be advantageous, the reproductive success of a deserting male must be greater than one who remains. Desertion will be more frequent when successful remating is likely, which depends on the frequency of other deserting males in the population, ${ }^{(68)}$ if many young survive with just one parent, or if the environment is so harsh that few offspring survive even with two parents. These factors are reflected in comparative analyses of mating systems in many species. Desertion or multiple mating by males is more common when the female can perform most of the parental care, i.e., parental care requirements are small or abundant resources enable successful rearing by a single parent..$^{(33)}$

If male investment is important, variance in male ability to invest can become a criterion by which females choose mates. For example, a female baboon displays a preference for mating with males who have already shown attention to her (protection from other baboons or predators) and

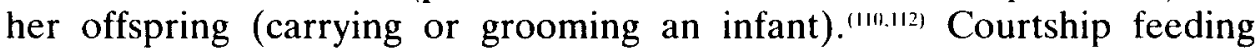


among birds may indicate ability to feed the female during incubation or the offspring later. ${ }^{(93)}$ Many male insects provide females with prey prior to mating, and females show evidence of basing mate choice on the size of such prey. ${ }^{(14)}$ When females and young will live on the male's territory, females discriminate on the basis of male territory quality. A female may achieve greater reproductive success with a male who already has one mate, given a rich territory. ${ }^{(9.5)}$ However, if the necessary paternal investment is behavior that cannot be shared among females, then it may be more advantageous to pair with an unmated male. ${ }^{12 \times 1}$

\section{Paternity Certainty}

When male investment is important, males generally act to ensure paternity by sequestering females or through aggressive behavior toward other males. ${ }^{(9 \times)}$ In many insects, other arthropods, and some mammals, males insert temporary gelatinous or mucosal mating plugs into the female oviduct following insemination, which apparently obstruct insemination by other males. ${ }^{(97)}$ Observations in the ring dove and other bird species have suggested that surveillance and guarding of females may be mechanisms to avoid cuckoldry. ${ }^{(x) !}$ For example, male bank swallows pursue the female whenever she flies from her nest burrow, but only when their mates are fertile; at other times they chase other females. ${ }^{(7)}$ Comparably, hoary marmot males guard their female mates only when they are fertile. ${ }^{(2)}$

When fertilization occurs externally, male parental care is more prevalent than female care. In internal fertilization, where the male no longer observes his sperm fertilizing the eggs, paternity confidence decreases. ${ }^{(112)}$ The relationship of confidence of paternity to the evolution of paternal care is not established, however. Maynard Smith ${ }^{\left({ }^{(s)}\right)}$ has argued that paternity per se will not be critical in selection for paternal care if paternity is equivalent for males who stay or who leave. Werren, Gross and Shine ${ }^{(122)}$ have shown, however, that paternity will play a role in the evolution of male paternal care in mating systems where a paternal male sacrifices mating opportunities outside of his territory. For paternal care to be adaptive, the total fitness a parental male gains from within his territory must be greater than the cost of losing promiscuous matings outside his territory. ${ }^{(122)}$

\section{CONGRUENCE OF HUMAN BEHAVIOR WITH PREDICTIONS FROM ANIMAL BEHAVIOR}

Given the importance of biological influences on patterns of parental care in animals, we would not be surprised to find parental behavior patterns in humans that were typical of other mammals with internal fertilization and 
gestation, lactation, and dependent offspring that require much care. For mammals, in environments where resources are not abundant and females with young cannot procure sufficient food, the survival of offspring may depend on help from fathers. Where there is a benefit from paternal aid, females may choose mates based on their willingness to provide resources or other help, and males generally act in ways that ensure the offspring are their own. The first variable, whether a father does remain to aid offspring, depends in animals on the interaction of his loss of other mating opportunities and the probability the offspring survive without his help. The second variable, the type of investment provided, depends on the interchangeability of the sexes. Males may be more likely to engage in activities that could be shared among several females, like territory defense. We now assess whether the factors that are important in determining paternal investment in animals also are relevant for humans.

\section{Male Capacity to Invest}

In traditional societies and other societies that have not undergone the demographic transition, a male's resources for investment do appear to affect the probability of successful reproduction. Yanomamo headmen (chiefs) have more wives and children than other males in the group. ${ }^{(22)}$ Headmen receive resources such as game, food, and labor from relatives and ai $i$ thus more successful in obtaining additional mates. Among the Yomut Turkmen, wealthy males are more frequently polygynous than are poor ones and therefore have a higher age-specific fertility rate. ${ }^{(57)}$ Among the Kipsigis, men with more acres of land have more wives, hence more children; their sons are also more likely to marry polygynously. ${ }^{(15)}$ The amount of land available is associated with the probability that children survive. ${ }^{(16)}$ Other examples clearly show this positive relationship for traditional societies. ${ }^{110.65 .74 .118)}$

In modern societies, the effect of resources on reproductive success can be seen only at the extremes of very high or very low resources. Very wealthy Americans have more surviving children and grandchildren than do Americans of average resources. ${ }^{\left(3.11^{2}\right) 11}$ The proportion of people with no recorded children is highest in low income or occupation categories. ${ }^{(1.2+1)}$ Among the contemporary middle class, the characteristics that people report to prefer in a mate show gender differences congruent with the importance of male resources and female child care in much of U.S. society: males prefer women who are physically attractive, while women value mates with a college education and good earning potential. ${ }^{(19)}$ In contrast, if the economic situation of men is insecure, the benefit from their investment is uncertain; they may be less likely to remain to rear children. ${ }^{\text {(3in) }}$

Other than providing tangible resources such as land, parents can invest directly by nursing, feeding or holding children, or less directly by providing 
protection or education. The type of investment that is advantageous depends on factors such as the ages of children. The trade-offs for men and women who are single parents appear to be similar, as discussed previously. In a situation where the father cooperates with the mother in rearing children, the allocation of his labor depends on the relationship of subsistence economy with child-care requirements and whether the presence of other mating opportunities bias some men to provide shareable resources. Different types of investment may be most beneficial for different men or different situations. In foraging societies, essential resources are not accumulable, unlike in agricultural or herding societies. Among the Aka pygmies, fathers spend more time holding their infants or in proximity to them than documented in any other society, although still less than do mothers ${ }^{(51)}$ Male and female subsistence activities overlap, with less division of labor than seen in other societies. Even so, within this group, fathers who hold their infants frequently tend to have fewer nontangible resources, as measured by the number of brothers (who cooperate in hunting) or the possession of leadership positions. ${ }^{(51)}$ The operation of an investment trade-off between direct care and resources is not clearly documented in the modern United States. Analyzing time use, Coverman and Shelley ${ }^{(23)}$ concluded that paternal child-care time was not strongly influenced by socioeconomic factors like education, income, or occupation. However, data from a 1965 sample showed a clear inverse relationship between paternal time in housework or child care and paternal income or hours spent in paid work. ${ }^{(23)}$ Data for a 1975 sample were less clear, perhaps showing a curvilinear relationship.

\section{Paternity Certainty}

When males do invest, they show evidence of concern for paternity. Daly, Wilson, and Weghorst ${ }^{(26)}$ suggested that male sexual jealousy, as evidenced by concern with female virginity and fidelity, functions specifically to clevate patcrnity confidence. The theoretical relationship between paternity certainty and investment has been modeled mathematically. ${ }^{172}$ Strong avunculate relationships (reliance on uncles more than on fathers) and matrilineal kinship have been correlated with high levels of premarital and extramarital sex and with serial marriage. Paternity certainty appears to affect patterns of inheritance of wealth: in societies that do not permit female promiscuity, a male's heirs are his sons, but in promiscuous societies, heirs are often his sisters' children. ${ }^{(+1.1+1 . .31)}$ There is evidence that lack of investment, child abuse and neglect, are more frequent when step-parents are in loco parentis with children.

The degree of male concern with controlling and inhibiting female sexual behavior has been attributed to concern over resource investment, particularly the inheritance of land. Reckoning descent through males is appar- 
ently more frequent where accumulation of wealth is possible. ${ }^{(4)}$ In stratified traditional societies, efforts to control female reproduction vary among classes or castes, with females at the lower end of the scale permitted more freedom of choice in marriage and also allowed more promiscuity. ${ }^{(24.31)}$ It has been reported for the modern United States that men and women in lower socioeconomic or job status levels first engage in coitus at a younger age. ${ }^{(123.124 .129)}$ Working class women who refrained from engaging in premarital sexual activities have been found to be more likely to marry a man from a higher social class. ${ }^{(31)}$

Descent rules in hierarchical social systems do correlate with some aspects of reproductive behavior. Patrilineal societies generally emphasize marriage, having social sanctions against divorce; women's resources are usually portable dowries. In bilateral systems, divorce is easier and more feasible, since women can generally inherit land. ${ }^{(46)}$ Over a wide range of cultures, in systems where the entire kin group, rather than a single male, is relied upon, there usually is relative tolerance of extramarital sex and frequent divorce. ${ }^{(5 \times)}$

\section{PROMOTING GENDER EQUALITY THROUGH SOCIAL POLICY CHANGES}

A study of the factors that have emerged as important across species (especially paternity certainty and male versus female capacity for investment) might provide some guidance to those who seek to address social and economic inequality. Could we make it more probable that men would help care for children by attenuating the effects that biological differences have on gender differences? Theorists have addressed both components of the present process. One, could we make it more likely that fathers will invest at all, i.e., increase the minimum paternal investment so there would be fewer mother-child families? Second, could the type of investment be altered so that more men engage in direct child care rather than breadwinning? We see both components as contributing to the present economic inequity between the sexes. Increasing the likelihood of any paternal investment requires either enhancing fathers' motivation or forcing them to contribute. Changing the usual type of investment requires making work more compatible with child rearing.

\section{Changes in Paternity Certainty}

Men, and males of other species, appear to act to protect paternity when their investment is important to the survival of offspring, particularly when the paternal male loses the opportunity for promiscuous matings. Current paternity tests are routinely used, but high-error rates limit their usefulness. 
Recent advances in molecular genetics could refine paternity testing to provide virtual certainty. ${ }^{\left({ }^{(1)}\right)}$ Beckman $^{\left({ }^{(1)}\right)}$ has suggested that use of these new paternity tests could encourage compliance with child support by fathers. This effect is certainly a possibility, all else being equal. Although such tests could be used to enforce support orders more effectively, given the father has an income, the real effects could be countered by other factors, e.g., the relative cost in the loss of other mating opportunities and the relative benefit from the paternal investment, compared to the mother's investment. Identifying paternity may have little effect on the larger legal and social problems of arranging adequate support for children. ${ }^{(126)}$

\section{Changes in Minimum Paternal Investment}

Women will obviously have an initially higher investment in offspring they carry and nurse, since men cannot bear children. Still, the financial risk of male desertion after conception could be changed so that the benefit of remaining to aid in rearing may exceed the cost of deserting and starting over. In fact, new child support laws have recently been enacted that could lower the incidence of father absence. To collect unpaid support, the federal government can now withhold wages and tax refunds, and use property lines. ${ }^{(113)}$ Through the 1988 Welfare Reform Bill, child-support payments are immediately withheld from a father's wages if the child is on welfare. Wisconsin's Child Support Assurance Program includes a standard for child-support awards that is set as a percentage of the noncustodial parent's income as well as immediate withholding of the child-support payments. ${ }^{(44)}$ Robins ${ }^{(1113)}$ estimated the effects of various services provided by the present child support enforcement programs on both the probability of receiving child support and on the amount of support received. His results indicate that the program has a positive effect on receipt of support and that child support reduces dependency on welfare programs. Mackey ${ }^{(i 6)}$ sees a system like ours, with some fathers cooperating in rearing children and others deserting, as basically unstable, because men who do contribute to rearing their own children are reluctant to pay (through taxes used for welfare benefits) for rearing other men's children. As the number of the children supported by the state increases, the number of men also supporting their own children, who are more economically vulnerable, would decrease.

\section{Changes in the Constraints on Male Investment}

Increasing the likelihood of direct child care by fathers would probably necessitate changes in the structure of work, as recommended by the 1980 National Conference on the Family. The proposals included flexible work 
schedules, paid and unpaid parental leaves, job-sharing, and consideration of family needs in ordering employee transferrals. ${ }^{\left({ }^{*}\right)}$ Other authors have suggested government support for child-care programs, expanded pregnancy leaves, and four-day work weeks, ${ }^{(4.3)}$ a "child allowance" for primary care-takers ${ }^{(3)}$ and school-based child care facilities combined with training in child rearing for all teenagers. ${ }^{\left({ }^{(1)}\right)}$ Fernandez (1986) supported corporate provision of informational activities including seminars on parenting issues.

There are already trends toward such changes in the nature of work. Increasingly, firms are providing on-site day-care centers or child-care support for working parents. About 3000 U.S. companies provide some form of child-care assistance; about 150 have day care centers at or near their offices. ${ }^{(11.5)}$ Legislation currently being debated in Congress would make provisions for child-care leaves of up to 10 weeks for either parent after childbirth or adoption. Some state legislatures have already passed parental leave measures. ${ }^{\left({ }^{(3)}\right)}$

In Great Britain, maternity rights legislation (especially the Employment Protection Act of 1975 and the Employment Consolidation Act of 1978) includes protection against dismissal while pregnant, the right to paid maternity leave, and the right, subject to certain length-of-service requirements, to reinstatement after pregnancy. ${ }^{\left({ }^{2}\right)}$ Sweden has instituted comprehensive day care, child-care training classes for high. school boys, and a voluntary parental training program for fathers of newborn babies. ${ }^{(8)}$ Both parents may choose to reduce their work days from eight to six hours. The parental insurance system allows one parent to stay home while receiving 90 percent of their usual wages, for the first 9 months after the birth of a child. ${ }^{(3.4)}$

\section{COMMENT}

The feasibility of any such schemes to change child-care roles depends on the existing proximate causes of behavior; if gender differences in parental behavior are physiologically determined, they could be resistant to consciously motivated change. The success of the policy changes in Sweden is equivocal; men have failed to share responsibility for housework and the care of children. ${ }^{(21)}$ Mackey ${ }^{(11)}$ sees little potential for developing equal contribution by men and women to child care. He suggests that society should repay women for the time spent in child-rearing through scholarships for higher education, similar to those provided by the GI Bill. The number of children and the number of years spent nurturing them would determine the amount of support awarded. Schwart $\mathrm{Z}^{(1+17)}$ encouraged businesses to have flexible scheduling expectations for women, depending on whether the family's needs must be accommodated. 
We have discussed factors correlated with biological sex differences that make current parental roles recalcitrant to change, but we do not yet know how malleable by experience is human parental behavior. Although human mothers spend more time in child care than do fathers, men vary widely across cultures in the amount of paternal investment they allocate..$^{\left({ }^{(k)}\right)}$ It is common for other animals to show several reproductive strategies, depending on age or local conditions (reviewed in Caro and Bateson). ${ }^{(21)}$ Clearly, changes must be made concurrently in many components of the system, given the complex relationships between garnering resources for survival and reproduction and caring for children directly.

Rossi ${ }^{(14+)}$ characterized parenting as a typical social behavior in which gender differences are influenced by biology. Berman ${ }^{(9)}$ however, concluded that physiological and behavioral studies have not shown the large sex differences in responsiveness to young that self-report studies have. Women exhibit more behavioral responsiveness to the young primarily in situations in which they are explicitly assigned the care-taking role or when characteristics of the experimental situation demand a responsible care-taking role (see also Lamb et al. ${ }^{(76)}$ ). Gender differences that are consistently shown are the responses of mothers and fathers to very young children, under one year old; fathers tend to play with them, while mothers comfort them. ${ }^{(7) 1}$

Mothers' better ability to comfort infants, the only consistent sex difference, appears to result from a multiply-detcrmined, interactive system that involves biological sex differences and sex differences in socialization. . $^{\left(\mathrm{N}_{0}\right)}$ There is some evidence that early behavioral gender differences could be affected by prenatal organizational effects of gonadal hormones (reviewed in Goy and McEwen). ${ }^{(47)}$ However, in many species, the ability to express gender-typical behavior depends on certain early experiences, including the differential behavior of adults to male and female infants. ${ }^{(54,51,8 \times)}$ In humans also, mothers have been found to behave differently to male and female children, even early in infancy. ${ }^{(36.84 .113)}$ Is comforting infants a skill that men can learn? Learning the motor behaviors involved in infant care appears to be facilitated by play-mothering when young (reviewed in Meaney, Stewart and Beatty). ${ }^{\left({ }_{6}\right)}$ Play-mothering is observed to be more frequent in females of human and other primate species (except the Barbary ape, where males as adults participate in the care and socialization of infants). ${ }^{(18)}$ Lancaster ${ }^{(77)}$ reported that young female vervet monkeys were rather clumsy in their initial efforts to care for an infant, having difficulty in orienting the infant's body and in getting the infant to cling to them. Differential experience can affect paternal behavior. Ember ${ }^{(32)}$ found that helping to care for younger children increased nurturing behavior in boys. In the United States, children reared in families with fathers who were unusually involved had less stereotyped sex-role attitudes than children from more traditional fami- 
lies, ${ }^{(76)}$ and the amount of time spent in housework and child care has shown a recent increase among young men.

As with most behavior, humans show some plasticity in response to environmental contingencies. Parental behavior is not impervious to experience. In the present synergistic system, however, physical differences between men and women, and any associated perceptual or behavioral differences, are magnified by cultural and social pressures. Under existing conditions for men, there has been little motivation for and little benefit from learning nurturance. We have no examples of contemporary environments where physical differences between the sexes in optimal reproductive conditions are countered by equally strong pressures to preserve investment in existing children.

We must decide how to intervene as a society to alleviate the present inequities. This is a moral and ethical question, regardless of how plastic are the psychological underpinnings of parental behavior. Indeed, Williams ${ }^{(1) ;}$ calls immoral most behavior naturally selected because of positive effects on short-term self-interest, proposing that the awareness of our underlying selfish motives, "ought to help in evaluating courses of action in relation to whatever one chooses as an ultimately worthy cause," and that we must "beware of manipulation by selfish individuals, or selfish institutions, or our own selfish genes" (p. 213). In particular, behavior that has a biological basis demands greater responsibility for its consequences.

The authors feel that if society could increase men's feelings of responsibility for direct care of children, it could interrupt the feminization of poverty and redress the gender inequality in earnings. The probable result would be increased variability and individuality within sexes. Small changes will have unpredictable effects, however. Eliminating the economic differential by providing public day-care centers or compensatory training in home maintenance and child care for men might only free more men from responsibility for supporting children. Increasing the certainty of paternity for men may not increase paternal behavior if the benefit from additional investment is not great, unless minimum paternal investment is mandated.

Given the gender differences in potential opportunities for reproducing through the lifespan, emotional attachment to and responsibility for each individual child could remain unequal. The drastic changes that would fully equalize child-care roles are not available. Society will be unable to expunge gender differences in the short-term effects on self-interest of caring for existing children; but short-term self-interest can eventually be countered by the enduring benefits of remaining a cooperative, reciprocating member of a social world where defecting from commitments has persistent and widespread long-term consequences. 
Acknowledgments: Preparation of this manuscript was supported in part by National Institutes of Health grant number HL07567 to EMH and a Henry Rutgers Research Fellowship to MAH. We would like to thank Monique Borgerhoff Mulder, Mildred Dickemann, Ira Gang, Mark Killingsworth, Bobbi Low, Randolph Nesse, Barbara Smuts, Paul Turke, Joseph Vogel, and Jack Worrall for their helpful comments and suggestions. All remaining errors are our own.

\section{REFERENCES}

(1) Bajema, C.J. "Relationship of Fertility to Occupational Status, IQ, Educational Attainment, and Size of Family of Origin: A Follow-up Study of a Male Kalamazoo Public School Population." Eugenics Quarterly, 15: 198-203, 1968.

(2) Barash, D.P. "Male Guarding and Gallivanting by Male Hoary Marmots (Marmota caligata)." Behavioral Ecology and Sociobiology, 9: 187-193, 1981.

(3) Bateman, A.J. "Intra-sexual Selection in Drosophila." Heredity 2: 349-368, 1948.

(4) Becker, G.S. A Treatise on the Family. Cambridge, MA: Harvard University, 1981.

(5) Becker, G.S. "Human Capital, Effort, and the Sexual Division of Labor." Journal of Labor Economics, 3: s33-s58, 1985.

(6) Beckman, J.II. "What are the Lawyers Doing? The Is Equals Ought Thing-Or What?" Paper presented at the Evolution and Human Behavior Conference, Ann Arbor, MI, 1988.

(7) Beecher, M., and I. Beecher. "Sociobiology of Bank Swallows: Reproductive Strategy of the Male." Science, 205: 1282-1285, 1979.

(8) Beer, W. R. Househusbands: Men and Housewark in American Families. New York: Praeger, 1983.

(9) Berman, P.W. "Are Women More Responsive Than Men to the Young? A Review of Developmental and Situational Variables." Psychological Bulletin, 88: 668-695, 1980.

(10) Betzig, L. "Mating and Parenting in Darwinian Perspective." Pp. 3-30 in Human Reproductive Behavior: A Darwinian Perspective, edited by L. Betzig, M. Borgerhoff Mulder and P. Turke. Cambridge: Cambridge University Press, 1988.

(11) Blau, F. D., and Beller, A. H., "Trends in earnings differentials by gender, 1971-1981." Industrial and Labor Relations Review, 41: 513-529, 1988.

(12) Blau, F.D., and M.A. Ferber. "Discrimination: Empirical Evidence from the United States." American Economic Review, 77: 316-320, 1987.

(13) Bloom, D.E. "The Labor-market Consequences of Delayed Childbearing." Paper presented at the American Statistical Association, Chicago, 1986.

(14) Blumstcin, P., and P. Schwartz. American Couples: Money, Work, Sex. New York: William Morrow, 1983.

(15) Borgerhoff Mulder, M. "On Cultural and Reproductive Success: Kipsigis Evidence." American Anthropologist, 89: 617-634, 1987.

(16) Borgerhoff Mulder, M. "Reproductive Success of Three Kipsigis Cohorts." in Reproductive Success: Studies of Selection and Adaptation in Contrasting Breeding Systems, edited by T.H. Clutton-Brock. Chicago: University of Chicago Press, in press.

(17) Brown, J. "A Note on the Division of Labor by Sex." American Anthropologist, 72: 1074-1078, 1970. 
(18) Burton, F.D. "The Integration of Biology and Behavior in the Socialization of Macaca sylvana of Gibraltar," in Primate Socialization, edited by F.E. Poirier. New York: Random House, 29-62, 1972.

(19) Buss, D.M., and M. Barnes. "Preferences in Human Mate Selection." Journal of Personality and Social Psychology, 50: 559-570, 1986.

(20) Caro, T.M., and P. Bateson. "Organization and Ontogeny of Alternative Tactics." Animal Behavior, 34: 1483-1499, 1986.

(21) Chabra, R. "Some Are (Still) More Equal Than Others." Sweden Now, 6: 20-23. 1980.

(22) Chagnon, N.A., M.V. Flinn, and T.F. Melancon. "Sex-ratio Variation Among the Yanomamo Indians." in Evolutionary Biology and Human Social Behavior, edited by N.A. Chagnon and W. Irons. North Scituate, MA: Duxbury Press, 290-320, 1979.

(23) Coverman, S., and J.F. Shelley. "Change in Men's Housework and Child-care Time, 1965-1975." Journal of Marriage and the Family, 48: 413-422, 1986.

(24) Daly, M., and M. Wilson. Sex, Evolution, and Behavior, 2nd ed. Belmont, CA: Wadsworth, 334, 1983.

(25) Daly, M., and M. Wilson. "Child Abuse and Other Risks of Not Living with Both Parents." Ethology and Sociobiology, 6: 197-210, 1985.

(26) Daly, M., M. Wilson, and S. Weghorst. "Male Sexual Jealousy." Ethology and Sociobiology, 3: 11-27, 1982.

(27) D'Andrade, R.G. "Sex Differences and Cultural Institutions." Pp. 174-204 in The Development of Sex Differences, edited by E.E. Maccoby. Stanford, CA: Stanford University Press, 1966.

(28) Dawkins, R., and R.T. Carlisle. "Parental Investment, Mate Desertion, and a Fallacy." Nature, 262: 131-132, 1976.

(29) Dickemann, M. "Female Infanticide, Reproductive Strategies, and Social Stratification: A Preliminary Model," pp. 321-367 in Evolutionury Biology and Human Social Behavior, edited by N.A. Chagnon and W. Irons. North Scituate, MA: Duxbury Press, 321-367, 1979a.

(30) Dickemann, M. "The Ecology of Mating Systems in Hypergynous Dowry Societies." Social Science Information, 18: 163-195, 1979b.

(31) Elder, G.H. "Appearance and Education in Marriage Mobility." American Sociological Review, 34: 510-533, 1969.

(32) Ember, C.R. "The Effects of Feminine Task Assignment on the Social Behavior of Boys." Ethos, 1: 424-439, 1973.

(33) Emlen, S.T., and L.W. Oring. "Ecology, Sexual Selection, and Evolution of Mating Systems." Science, 197: 215-223, 1977.

(34) Ericsson, Y. "Sweden," pp. 138-146 in Women Workers in Fifteen Countries, edited by J. Farley. Ithaca, NY: ILR Press, 1985

(35) Essock-Vitale, S.M. "The Reproductive Success of Wealthy Americans." Ethology and Sociobiology, 5: 45-49, 1982.

(36) Fagot, B.I. "Sex Differences in Toddler's Behavior and Parental Reaction." Developmental Psychology, 10: 554-558, 1974.

(37) Fernandez, J.P. Child Care and Corporate Productivity: Resolving Family/Work Conflicts. Lexington, MA: Lexington Books, 1986.

(38) Flinn, M. "Parent-Offspring Interactions: Genetic and Step-Relationships in Trini- 
dad." Paper presented at the Midwestern Evolution and I Iuman Behavior Conference, Ann Arbor, MI, 1987.

(39) Friedan, B. The Second Stage. New York: Summit Books, 1981.

(40) Fuchs, V.R. "His and Hers: Gender Differences in Work and Income, 1959-1979." Journal of Labor Economics, 4: S245-S272, 1986.

(41) Gaulin, S.J.C., and A. Schlegcl. "Patcrnal Confidence and Paternal Investment: A Cross-cultural Test of a Sociobiological Hypothesis." Ethology and Sociobiology, 1: 301-309, 1980.

(42) George, V., and P. Wilding. Motherless Families. London: Routledge and Kegan Paul, 1972.

(43) Gerson, M.-J., J.L. Alpert, and M.S. Richardson, "Mothering: The View from Psychological Research." Signs: Journal of Women in Culture and Society, 9: 434-453, 1984.

(44) Gordon, A.R. "Child Support Policy." American Economic Association, CSWEP Newsletter, May 1988.

(45) Grafen, A., and R. Sibley. "A Model of Mate Desertion." Animal Behaviour, 26: 645-652, 1978.

(46) Greene, P.J. "Promiscuity, Paternity, and Culture." American Ethnologist, 5 151$159,1978$.

(47) Goy, R.W., and B.S. McEwen. Sexual Differntiation of the Brain. Cambridge, MA: MIT Press, 1980.

(48) Gwynne, D.T. "Sexual Difference Theory: Mormon Crickets Show Role-reversal in Mate Choice." Science, 213: 779-780, 1981.

(49) Hartung, J. "On Natural Selection and the Inheritance of Wealth." Current Anthropology, 17: 607-613, 1976.

(50) Hartung J. "Paternity and Inheritance of Wealth." Nature, 291: 267-268, 1981.

(51) Hewlett, B.S. "Sexual Selection and Paternal Investment among Aka Pygmies," pp. 263-276 in Human Reproductive Behaviour: A Darwinian Perspective, edited by L. Betzig, M. Burgerhoff Mulder and P. Turke. Cambridge: Cambridge University Press, 1988.

(52) Hill, C.R., and F.P. Stafford. "Parental Care of Children: Time Diary Estimates of Quantity, Predictability, and Variety." Journal of Human Resources, 15: 219-239, 1980.

(53) Hill, K. and H. Kaplan. "Tradeoffs in Male and Female Reproductive Strategies among the Ache: Part 2," pp. 291-305 in Human Reproductive Behaviour: A Darwinian Perspective, edited by L. Betzig, M. Borgerhoff Mulder and P. Turke. Cambridge: Cambridge University Press, 1988.

(54) Hinde, R.A. "Development of Social Behavior," pp. 1-68 in Behavior of Nonhuman Primates, edited by A.M. Schrier and F. Stolhitz. New York: Academic Press, Volume 3, 1971.

(55) Hipgrave, T. "Child Rearing by Lone Fathers," pp. 149-166 in Changing Patterns of Childbearing and Child Rearing, edited by R. Chester, P. Diggory, and M.B. Sutherland. London: Academic Press, 1981.

(56) Hrdy. S.B., and G.C. Williams. "Behavioral Biology and the Double Standard," pp. 3-17 in Social Behavior of Female Vertebrates, edited by S.K. Wasser. New York: Academic Press, 1983. 
(57) Irons, W. "Cultural and Biological Success," pp. 257-272 in Evolutionary Biology and Human Social Behavior, edited by N.A. Chagnon and W. Irons. North Scituate, MA: Duxbury Press, 1979.

(58) Irons, W. "Human Female Reproductive Strategies," pp. 169-213 in Social Behavior of Female Vertebrates, edited by S.K. Wasser. New York: Academic Press, 1983.

(59) Jenni, D.A. "Evolution of Polyandry in Birds." American Zoologist, 14: 129-144, 1974.

(60) Jensen, G.D., R.A. Bobbitt, and B.N. Gordon. "The Development of Maternal Independence in Mother-Intant Pigtailed Monkeys, Macaca nemestrina, pp. 43-54 in Social Communication Among Primates, edited by S.A. Altmann. Chicago: University of Chicago Press, 1967.

(61) Joshi, H., and M.-L. Newell. "Pay Differentials and Parenthood: Analysis of Men and Women born in 1946." Report to the Department of Employment. London: The Centre for Population Studies, University of London, 1986.

(62) Juster, F.T. "A Note on Recent Changes in Time Use," pp. 313-332 in Time, Goods, and Well-Being, edited by F.T. Juster and F. Stafford. Ann Arbor, MI: Institute for Social Research, 1985.

(63) Kantrowitz, B., and P. Wingert. "Parental Leave Cries to Be Born." Newsweek (January) 65, 1989.

(64) Kaplan, C., and V. Gregory. Feminization of Poverty: An Update. Washington, DC: Wider Opportunities for Women, Inc., 1983.

(65) Kaplan, H., and K. Hill. "Hunting Ability and Reproductive Success among Male Ache Foragers." Current Anthropology, 26: 131-133, 1985.

(66) Katz, M., and M. Konner. "The Role of the Father: Anthropological Perspective," pp. 189-222 in The Role of the Father in Child Development (Rev. Ed.), edited by M. Lamb. New York: Wiley, 1981.

(67) Kinzey, W.G. "A Primate Model for Human Mating Systems," pp. 105-114 in The Evolution of Human Behavior: Primate Models, edited by W. G. Kinzey. Albany, NY: The State University of New York Press, 1989.

(68) Kitcher, P. Vaulting Ambition: Sociobiology and the Quest for Human Nature. Cambridge, MA: The MIT Press, 1985.

(69) Kleiman, D.G. "Monogamy in Mammals." Quarterly Review of Biology, 52: 39-69. 1977.

(70) Kleiman, D.G., and J.R. Malcolm. "The Evolution of Male Parental Investment in Mammals," pp. 347-387 in Parental Care in Mammals, edited by D.J. Gubernick and P.H. Klopfer. New York: Plenum Press, 1981.

(71) Knowlton, N. "Parental Care and Sex Role Reversal," pp. 203-222 in Current Problems in Sociobiology, edited by. Kings College Sociobiology Group. Cambridge: Cambridge University Press, 1982.

(72) Kurland, J. "Paternity, Mother's Brother and Human Sociality," pp. 145-180 in Evolutionary Biology and Human Social Behavior, edited by N.A. Chagnon and W. Irons. North Scituate, MA: Duxbury Press, 1979.

(73) Lack, D. Ecolvgical Adaptations for Breeding in Birds. London: Metheun, 1968.

(74) Lamb, M.E. "Father-infant and Mother-infant Interaction in the First Year of Life." Child Development, 48: 167-181, 1977.

(75) Lamb, M.E., J.H. Pleck, E.L. Charnov, and J.A. Levine. "Paternal Behavior in Humans." American Zoologist, 25: 883-894, 1985a. 
(76) Lamb, M.E., J.H. Pleck, and J.A. Levine. "The Role of the Father in Child Development: The Effects of Increased Paternal Involvement." Advances in Clinical Child Psychology, 8: 229-266, 1985b.

(77) Lancaster, J.B. "Play-mothering: The Relations Between Juvenile Females and Young Infants Among Free-Ranging Vervet Monkeys (Cercopithecus aethiops), Folia Primatologica, 15: 161-182, 1971.

(78) Lancaster, J.B. "Human Adolescence and Reproduction: An Evolutionary Perspective," pp. 17-37 in School-age Pregnancy and Parenthood: Biosocial Dimensions, edited by J.B. Lancaster and B.A. Hamburg. Hawthorme, NY: Aldine De Gruyter, 1986.

(79) Low, B. "Resources, Reproductive Success, and Lineage Growth in 19th Century Sweden." Paper presented at the Midwestern Evolution and Human Behavior Conference, Ann Arbor, Michigan, 1987.

(80) Lumpkin, S. "Female Manipulation of Male Avoidance of Cuckoldry Behavior in the Ring Dove," pp. 91-112 in Social Behavior of Female Vertebrates, edited by S.K. Wasser. New York: Academic Press, 1983.

(81) Mackey, W.C. Fathering Behaviors: The Dynamics of the Man-Child Bond. New York: Plenum, 1985.

(82) MacLennan, E., and N. Fonda. "Great Britain," pp. 90-111 in Women Workers in Fifteen Countries, edited by J. Farley. Ithaca, NY: ILR Press, 1985.

(83) Mason, K. "Comment: The Social Institutions of Occupational Segregation," pp. 8183 in Women and the Workplace, cditcd by M. Blaxall and B. Reagan. Chicago: University of Chicago Press, 1976.

(84) Maynard Smith, J. "Parental Investment: A Prospective Analysis." Animal Behaviour. 25: 1-9, 1977.

(85) Maynard Smith, J. The Evolution of Sex. Oxford: Alden Press, 1978.

(86) Meaney, M.J., J. Stewart, and W.W. Beatty. "Sex Differences in Social Play: The Socialization of Sex Roles." Advances in the Study of Behavior, 15: 1-58, 1985.

(87) Mincer, J., and S. Polachek. "Family Investments in Human Capital: Earnings of Women." Journal of Political Economy, 82: s76-s108, 1974.

(88) Mitchell, G.D. "Attachment Differences in Male and Female Infant Monkeys." Child Development, 39: 611-620, 1968.

(89) Moss, H. "Early Sex Differences and Mother-infant Interaction," pp. 149-164 in Sex Differences in Behavior, edited by R.M. Richart and R.L. Vande Wiele. New York: Wiley, 1967.

(90) Nakamura, C.Y., S.J. McCarthy, C. Rothstein-Fisch, and L.D. Winges. "Interdependence of Child-care Resources and the Progress of Women in Society," Psychology of Women Quarterly 6 (1981): 26-40.

(91) Nerlove, S.B. "Women's Work Load and Infant Feeding Practices: A Relationship with Demographic Implications." Ethnology, 13: 207-214, 1974.

(92) Nielsen, J.M., and R. Endo. "Marital Status and Socioeconomic Status: The Case of Female-headed Families." International Journal of Women's Studies, 6: 130-147, 1983.

(93) Nisbet, I.C.T. "Courtship-feeding, Egg-size and Breeding Success in Common Terns." Nature, 24: 141-142, 1973.

(94) Northcutt, H.C. "Who Stays Home? Working Parents and Sick Children." International Journal of Women's Studies, 6: 387-394, 1983. 
(95) Orians, G.H. "On the Evolution of Mating Systems in Birds and Mammals." American Naturalist, 103: 587-603, 1969.

(96) Ortner, S.B. "Gender and Sexuality in Hierarchical Societies: The Case of Polynesia and Some Comparative Implications," pp. 359-409 in Sexual Meanings: The Cultural Construction of Gender and Sexuality, edited by S.B. Ortner and H. Whitehead. Cambridge: Cambridge University Press, 1981.

(97) Parker, G.A. "Sperm Competition and its Evolutionary Consequences in Insects." Biological Review, 45: 525-567, 1970.

(98) Parker, G.A. "Courtship Persistence and Female-guarding as Male Time Investment Strategies." Behaviour, 48: 157-184, 1974.

(99) Petrie, M. "Mate Choice in Role-reversed Species," pp. 167-179 in Mate Choice, edited by P. Bateson. Cambridge: Cambridge University Press, 1983.

(100) Pleck, J.H. "Husband's Paid Work and Family Roles: Current Research Issues." pp. 251-333 in Research in the Interweaves of Social Roles: Family and Jobs, vol. 3, edited by H.Z. Lopata and J.H. Pleck. Greenwich, CT: Jai Press, 1983.

(101) Pleck, J.H. Working Wives/Working Husbands. Beverly Hill, CA: Sage, 1985.

(102) Ridley, M. "Paternal Care." Animal Behaviour, 26: 904-932, 1978.

(103) Robins, P.K. "Child Support, Welfare Dependency, and Poverty." American Economic Review, 7: 768-788, 1986.

(104) Rossi, A.S. “A Biosocial Perspective on Parenting." Daedalus, 106 (Spring): 1-31, 1977.

(105) Rossi, A.S. "Gender and Parenthood," pp. 161-191 in Gender and the Life Course, edited by A.S. Rossi. New York: Aldine, 1985.

(106) Salkever, D. "Children's Health Problems: Implications for Parental Labor Supply and Earnings," pp. 221-251 in Economic Aspects of Health, edited by V.R. Fuchs. Chicago: University of Chicago Press, 1982.

(107) Schwartz, F. "Management Women and the New Facts of Life." Harvard Business Review, 67 (Jan.-Feb.): 65-67, 1989.

(108) Smith, R.L. "Paternity Assurance and Altered Roles in the Mating Behaviour of a Giant Water Bug, Abedus herberti (Heteroptera: Belostomatidae)." Animal Behaviour, 27: 716-725, 1979.

(109) Smouse, P., and R. Chakraborty. "The Use of Restriction Fragment Length Polymorphisms in Paternity Analyses." American Journal of Human Genetics, 38: 918-939, 1986.

(110) Smuts, B.B. Sex and Friendship in Baboons. Hawthorne, NY: Aldine, 1985.

(111) Sorensen, E. "Occupational Segregation and the Gender-Wage Gap: A Review and Some New Findings," in Comparable Worth: Analyses and Evidence, edited by M.A. Hill and M.R. Killingsworth. Ithaca, NY: ILR Press, forthcoming.

(112) Strum, S.C. "Agonistic Dominance in Male Baboons: An Alternate View." International Journal of Primatology, 3: 175-202, 1982.

(113) Thomas, E.B., P.H. Leiderman, and J.P. Olson. "Neonate-mother Interaction During Breast Feeding." Developmental Psychology, 6: 110-118, 1972.

(114) Thornhill, R. "Sexual Selection and Paternal Investment in Insects." American Naturalist, 110: 153-163, 1976.

(115) Trost, C. "Child-care Center at Virginia Firm Boosts Worker Morale and Loyalty." Wall Street Journal (February 12): 27, 1987. 
(116) Trivers, R. "Parental Investment and Sexual Sclcction," pp. 136-179 in Sexual Selection and the Descent of Man, edited by. B. Campbell. Chicago: Aldine, 1972.

(117) Trivers, R. Social Evolution. Menlo Park, CA: Benjamin/Cummings, 1985.

(118) Turke, P., and L.L. Betzig. "Those Who Can Do: Wealth, Status, and Reproductive Success on Ifaluk." Ethology and Sociobiology, 6: 79-87, 1985.

(119) U.S. Department of Labor. Bureau of Labor Statistics. "Usual Weekly Earnings of Wage and Salary Workers: Second Quarter, 1987." News. USDL87-327 (July 30), 1987.

(120) Vining, D.R. "Social versus Reproductive Success: 'The Central Theoretical Problem of Human Sociobiology." Behavioral and Brain Sciences, 9: 167-216, 1986.

(121) Wells, K.D. "Courtship and Parental Behaviour in a Panamanian Poison-arrow Frog." (Dendrobates auratus), Herpetologica, 34: 148-155, 1978.

(122) Werren, J.H., M.R. Gross, and R. Shine. "Paternity and the Evolution of Male Parental Care." Journal of Theoretical Biology, 82: 619-631, 1980.

(123) Weinberg, M.S., and C.J. Williams. "Sexual Embourgeoisment? Social Class and Sexual Activity: 1938-1970." American Sociological Review, 45: 33-48, 1980.

(124) Weinrich, J.D. "Human Sociobiology: Pair-bonding and Resource Predictability (Effects of Social Class and Race)." Behavioral Ecology and Sociobiology, 2: 91-118, 1977.

(125) Williams, G.C. "A Sociobiological Expansion of Evolution and Ethics," pp. 179-214 in Evolution and Ethics, edited by J. Paradis and G.C. Williams. Princeton, NJ: Princeton University, 1989.

(126) Wilson, M. "Impact of the Uncertainty of Paternity on Family Law." University of Toronto Faculty of Law Review, 45: 216-242, 1987.

(127) Wilson, M.I., M. Daly, and S.J. Weghorst. "Household Composition and the Risk of Child Abuse and Neglect." Journal of Biosocial Science, 12: 333-340, 1980.

(128) Wittenberger, J.F., and R.L. Tilson. "The Evolution of Monogamy: Hypotheses and Evidence." Annual Review of Ecology and Systematics, 11: 197-232, 1980.

(129) Zelnik, M., J. Kantner, and K. Ford. Adolescent Pathways to Pregnancy. Beverly Hill, CA: Sage Publications, 1982. 